\title{
Communication
}

[Comunicação]

\section{Identification of Porcine parvovirus from wild boars by partial sequencing of the VP-2 coding gene}

[Identificação de parvovírus suíno em javalis a partir do sequenciamento parcial do gene VP-2]

\author{
V.L.A. Ruiz ${ }^{1}$, J.G. Bersano ${ }^{1}$, P.E. Brandão ${ }^{2}$, F. Gregori $^{1}$, R.M. Soares ${ }^{2}$, \\ E.M.C. Villalobos ${ }^{1}$, L.J. Richtzenhain ${ }^{2}$ \\ ${ }^{1}$ Centro de Pesquisa e Desenvolvimento de Sanidade Animal - Instituto Biológico \\ Av. Conselheiro Rodrigues Alves, 1252 \\ 04014-002 - São Paulo, SP \\ ${ }^{2}$ Faculdade de Medicina Veterinária e Zootecnia - USP - São Paulo, SP
}

Porcine parvovirus (PPV) is one of the most frequent pathogens associated with reproductive disorders in swine, even though few cases have been described in wild boars (Sus scrofa), all of these based on antibody detection, mainly by ELISA and hemagglutination inhibition tests. In 1994, blood samples were collected from 108 wild hogs from North Carolina and Tennessee (USA) and antibody titers to PPV were found in 15 (14\%) samples (New et al., 1994). By 1998, Saliki et al. (1998) tested 120 blood samples from wild swine in Oklahoma, USA, and had found antibody against porcine parvovirus in $17 \%$ of them. Later, 20 feral hogs from a newly discovered population from Kansas, USA, were shot and examined. Those hogs were generally healthy, although serological evidence indicated that $70 \%$ of the animals were exposed to PPV (Gipson et al., 1999). Antibodies were also detected in $10 \%$ of the serum samples from 78 European wild boars harvested during the 19992000 hunting season in south-central Spain (Vicente et al., 2002). Serologic evidence of exposure to porcine parvovirus was investigated in 219 wild boars from a commercial farm in Croatia and $41.6 \%$ of the samples showed positive results both in ELISA and hemagglutination inhibition test (Roić et al., 2005). Serum samples collected from 178 shot wild boars were tested for the presence of antibodies against PPV by ELISA throughout Slovenia during the hunting season 2003-2004,

Recebido em 18 de dezembro de 2008

Aceito em 1 de setembro de 2009

E-mail: letticie@biologico.sp.gov.br demonstrating antibodies in 87 sera (49\%) (Vengust et al., 2006).

PPV and anti-PPV antibodies are widely spread among Brazilian swine herds (Gouveia et al., 1984; Bersano et al., 1995; Soares et al., 1999), but only one antibody investigation on wild boars has been made so far in Brazil (Bersano et al., 1999), where wild boars commercial population and its contact with swine herds have increased in the last few years.

Although the occurrence of parvovirus antibodies in feral swine in various parts of the word is well documented, it is important carrying out direct detection of the virus to confirm the infection in wild boars. The aim of this study was to survey for PPV DNA in organ samples from wild boars bred for commercial purposes by PCR (NS-1 and VP-2 coding gene) and DNA sequencing targeting the VP-2 coding gene.

Pool of organs (spleen, kidney, liver, lymph nodes, and tonsil) from three adults and asymptomatic wild boars (bred for commercial purposes) of Paraguaçu Paulista, SP, were submitted to PPV detection. The DNA from homogenates was extracted following a method described elsewhere (Chomczynski, 1993) and stored at $-20^{\circ} \mathrm{C}$ until required. These samples were submitted to PPV detection by a screening nested-PCR directed to the highly conserved NS-1 coding sequence and the enzymatic 
amplification for NS-1 coding gene was carried out in $50 \mu \mathrm{L}$ of PCR mixture containing $0.5 \mathrm{mM}$ of outer primers (P1 and P6; Table 1), 2.5U DNA polymerase ${ }^{1}, 1 \mathrm{x}$ PCR reaction buffer, $1.5 \mathrm{mM} \mathrm{MgCl}_{2}, 0.2 \mathrm{mM}$ of each dNTPs, $5 \mu \mathrm{L}$ of extracted DNA, and ultrapure water as diluent (Soares et al., 1999).

PCR amplification was performed in thermo cycler ${ }^{2}$ under the following conditions: 1 cycle at $95^{\circ} \mathrm{C}$ for five minutes, 35 cycles of $95^{\circ} \mathrm{C}$ for 45 seconds, $55^{\circ} \mathrm{C}$ for 60 seconds, $72^{\circ} \mathrm{C}$ for 90 seconds and followed by a final heating at $72^{\circ} \mathrm{C}$ for 10 minutes for the extension. An identical amplification procedure was adopted in the nested-PCR, except for the use of a different set of primers (inner primers, P2 and P5; Table 1) and a volume of $5 \mu \mathrm{L}$ from the first round amplification products as sample (Soares et al., 1999).

In order to confirm these results, a nested-PCR for VP-2 coding gene was carried out. Amplification conditions for VP-2 coding gene nested-PCR were performed as follows: $5 \mu \mathrm{L}$ of extracted DNA in a final volume of $50 \mu \mathrm{L}$, containing 50pmol each outer primer (P3 and P8; Table 1), 2U DNA polymerase ${ }^{1}, 1 \mathrm{x}$ PCR reaction buffer, $1.5 \mathrm{mM} \mathrm{MgCl} \mathrm{mM}_{2}, 0.2 \mathrm{mM}$ of each dNTP and ultrapure water as diluent (Soares et al., 2003).

After an initial heating at $94^{\circ} \mathrm{C}$ for three minutes, 35 cycles at $94^{\circ} \mathrm{C}$ for 45 seconds, $55^{\circ} \mathrm{C}$ for 60 seconds, and $72^{\circ} \mathrm{C}$ for 90 seconds, and one cycle at $72^{\circ} \mathrm{C}$ for 10 minutes were carried out. NestedPCR was performed with $5 \mu \mathrm{L}$ of the primary amplification template and inner primers ( $\mathrm{P} 4$ and P7; Table 1). The thermal cycles for the nested assay were the same, except for an amplification phase of 25 cycles (Soares et al., 2003).

PCR products were resolved in $2.0 \%$ agarose gels electrophoresis with standard TBE buffer and stained with $0.5 \mu \mathrm{g} / \mathrm{mL}$ ethidium bromide.

Amplified products with the expected sizes of VP-2 gene were excised from the gel and purified using a commercial $\mathrm{kit}^{3}$. Sequencing reactions were performed using the

\footnotetext{
${ }^{1}$ Invitrogen - São Paulo, Brazil.

${ }^{2}$ Eppendorf Mastercycler ${ }^{\circledR}$ Gradient Thermal Cycler Hamburg, Germany.

${ }^{3}$ Concert $^{\mathrm{TM}}$ Rapid Gel Extraction System, Gibco-BRL ${ }^{\circledR}$ Rochville, USA.
}

dideoxynucleotide chain-termination method $^{4}$ and sequences were determined with an automated sequencer ${ }^{5}$, according to instructions of the manufacturer. Nucleotide sequencing was performed in both directions using the primers P4 and P7 for the VP-2 nested-PCR product and generated sequences were aligned using CLUSTAL W software (Thompson et al., 1994).

The degree of similarity among sequences at both nucleotide and amino acid levels were compared to NADL-2 (accession number NC 001718) and Kresse (accession number U44978) strains of PPV using BIOEDIT v. 7.0.9 software (Hall, 1999). BIOEDIT was also used calculate the identity matrix of VP-2 sequences between Brazilian PPV (accession number AY145472 to AY145500) and sequences from the present study (accession number EF026981 and EF026982).

The nested-PCR directed to the highly conserved NS-1 coding sequence resulted in two positive samples. These samples were then submitted to a nested-PCR using primers directed to the structural protein VP-2 coding sequence in order to amplify the last 492 nucleotides of the 3'-end of this ORF, corroborating the first results. The entire VP2-coding sequence of PPV comprises 1,740 nucleotides (Bergeron et al., 1993), over which it was amplified a 492bp fragment and analyzed a 331 nucleotide consensus area, in terms of identity with homologous sequences. These sequences (accession number EF026981 and EF026982) were compared to homologous sequences from the NADL-2 strain and Kresse strain, demonstrating $100 \%$ of nucleotide identity.

Comparing the nucleotide sequences obtained in this study with others previously published, it is possible to notice that both Brazilian wild boar strains are included in genotypic group A, as stated by Soares et al. (2003). This classification is not associated with clinical presentation or geographical origin of the samples.

${ }^{4}$ Big Dye ${ }^{\circledR}$ Terminator v3.1 Cycle Sequencing kit, Applied Biosystems - Foster City, USA.

${ }^{5}$ ABI Prism ${ }^{\circledR} 377$ DNA Sequencer, Applied Biosystems Foster City, USA. 
Table 1. Oligonucleotide primers used for PCR amplification of porcine parvovirus DNA

\begin{tabular}{ccccc}
\hline $\begin{array}{c}\text { Target } \\
\text { (coding } \\
\text { gene) }\end{array}$ & Reaction & Primer & Sequence $\left(5^{\prime}{ }^{\prime} 3^{\prime}\right)$ & $\begin{array}{c}\text { Fragment } \\
\text { size }\end{array}$ \\
\hline \multirow{2}{*}{ NS-1 } & PCR & P1 & ATA CAA TTC TAT TTC ATG GGC CAG C & $330 \mathrm{bp}$ \\
& Nested- & P2 & TAT GTT CTG GTC TTT CCT CGC ATC & \\
& PCR & P5 & ACC TGA ACG TAT GGC TTT GAA TTG G & $127 \mathrm{bp}$ \\
\hline \multirow{2}{*}{ VP-2 } & PCR & P3 & GGC ACC ACT AAA CCT AGA AAA TAC A & \multirow{2}{*}{$558 \mathrm{bp}$} \\
& Nested- & P4 & CAA TGA TAG TAG TAC ATG ATT AAC CAA & \\
& PCR & P7 & CAC TTT TAC CTT CAG ATC CAA TAG G & $492 \mathrm{bp}$ \\
\hline
\end{tabular}

${ }^{1} \overline{\text { Soares et al. }} \overline{(1999,2003)}$.

Using the NADL-2 Porcine parvovirus complete genome sequence (accession number NC_001718) as reference for the nucleotide positions, it was observed one to three substitutions depending on the Brazilian strain which has been compared to the generated sequences (position 4462: $\mathrm{A} \rightarrow \mathrm{C} / 4472: \mathrm{A} \rightarrow \mathrm{C} /$ 4473: $A \rightarrow G)$. When those sequences were translated, these substitutions showed non-silent mutations in the VP-2 residues 551 (Glu $\rightarrow$ Asp) and 555 (Asn $\rightarrow$ His or Asn $\rightarrow$ Arg), all polar to polar amino acid substitutions (Alnahi, 1991) in the surface area of the domain 1 of the protein, as observed in VP-2 PDB identification 1K3V (Simpson et al., 2002) using Cn3D 4.1 software.
The close genetic identity among swine and wild boar-derived PPV strains suggests that both host species share a common variant of the virus that freely circulates between them, posing a risk to the control of PPV-caused diseases in herds in which these are kept in close proximity.

These results show for the first time the direct detection of porcine parvovirus in wild boars from a commercial farm.

Keywords: wild boar, nucleotide sequence, PCR, PPV

\section{RESUMO}

Este estudo descreve a detecção e a identificação de DNA de parvovírus suíno (PVS) em amostras de órgãos de dois javalis, por PCR e sequenciamento direcionado ao gene VP-2. Pools de órgãos (baço, rins, figado, linfonodos e tonsila) de três javalis adultos e assintomáticos de Paraguaçu Paulista, SP, criados com propósitos comerciais, foram submetidos à detecção de PVS, resultando em duas amostras positivas após reações de nested-PCR direcionadas aos genes NS-1 e VP-2. Os fragmentos parciais de VP-2 foram sequenciados e comparados a sequências homólogas de cepas NADL-2 e Kresse, demonstrando identidade nucleotidica de 100\%. Com relação a 29 cepas de PVS previamente isoladas no Brasil, o grau de identidade nucleotídica variou de 99 a 100\% (uma a três substituições de nucleotídeos). Estes resultados demonstram, pela primeira vez, a detecção direta por PCR de parvovírus suíno em javalis, confirmada por análise de sequenciamento genético.

Palavras-chave: javali, sequência nucleotidica, PCR, PVS

\section{REFERENCES}

ALNAHI, H.G. A new classification of amino acid residues by using machine learning approach. Biophysical and biochemical measurements. In: ANNUAL INTERNATIONAL CONFERENCE OF THE IEEE ENGINEERING IN MEDICINE AND BIOLOGY SOCIETY, 13., 1991, Florida.
Proceedings... Los Alamitos, CA: Institute of Electrical \& Electronics Engineers (IEEE), 1991. p.1482-1484.

BERGERON, J.; MENEZES, J.; TIJSSEN, P. Genome organization and mapping of transcription and translation products of the NADL-2 strain of porcine parvovirus. Virology, v.197, p.86-98, 1993. 
BERSANO, J.G.; BASTOS, G.M.; SOARES, R.M. et al. Isolamento e identificação do Parvovírus Suíno (PVS) no Estado de São Paulo. Arq. Inst. Biol. São Paulo, v.62, p.37, 1995. (Resumo).

BERSANO, J.G.; VILLALOBOS, E.M.C.; CUNHA, E.M.S. et al. Dados preliminares sobre a pesquisa de anticorpos anti-Parvovirus Suíno (PVS) e Doença de Aujeszky (DA) em javalis (Sus scrofa) no Estado de São Paulo. Arq. Inst. Biol. São Paulo, v.66, p.38, 1999. (Resumo).

CHOMCZYNSKI, P. A reagent for the singlestep simultaneous isolation of RNA, DNA and proteins from cells and tissue samples. Biotechnology, v.15, p.532-537, 1993.

GIPSON, P.S.; VEATCH, J.K.; MATLACK, R.S. et al. Health status of a recently discovered population of feral swine in Kansas. J. Wildl. Dis., v.35, p.624-627, 1999.

GOUVEIA, A.M.G.; GOMEZ, M.C.; REIS, R. Alterações reprodutivas e prevalência de anticorpos inibidores de hemoaglutinação para o Parvovírus Suíno no Estado de Minas Gerais. Pesq. Vet. Bras., v.4, p.17-22, 1984.

HALL, T.A. BioEdit: a user-friendly biological sequence alignment editor and analysis program for Windows 95/98/NT. Nucleic Acids Symp. Ser., v.41, p.95-98, 1999.

NEW, J.C.; DELOZIER, K.; BARTON, C.E. et al. A serologic survey of selected viral bacterial diseases of European wild hogs, Great Smoky Mountains National Park, USA. J. Wildl. Dis., v.30, p.103-106, 1994.

ROIĆ, B.; CAJAVEC, S.; TONCIC, J. et al. Prevalence of antibodies to porcine parvovirus in wild boars (Sus scrofa) in Croatia. J. Wildl. Dis., v.41, p.796-799, 2005.

SALIKI, J.T.; RODGERS, S.J.; ESKEW, G. Serosurvey of selected viral and bacterial diseases in wild swine from Oklahoma. J. Wildl. Dis., v.34, p.834-838, 1998.

SIMPSON, A.A.; HEBERT, B.; SULLIVAN, G.M. et al. The structure of porcine parvovirus: comparison with related viruses. J. Mol. Biol., v.315, p.1189-1198, 2002.

SOARES, R.M.; DURIGON, E.L.; BERSANO, J.G. et al. Detection of Porcine parvovirus DNA by the polymerase chain reaction assay using primers to the highly conserved nonstructural protein gene, NS-1. J. Virol. Methods, v.78, p.191-198, 1999.

SOARES, R.M.; CORTEZ, A.; HEINEMANN, M.B. et al. Genetic variability of Porcine parvovirus isolates revealed by analysis of partial sequences of the structural coding gene VP-2. $J$. Gen. Virol., v.84, p.1505-1515, 2003.

THOMPSON, J.D.; HIGGINS, D.G.; GIBSON, T.J. CLUSTAL W: improving the sensitivity of progressive multiple sequence alignment through sequence weighting, position-specific gap penalties and weight matrix choice. Nucleic Acids Res., v.22, p.4673-4680, 1994.

VENGUST, G.; VALENCAK, Z.; BIDOVEC, A. A serological survey of selected pathogens in wild boar in Slovenia. J. Vet. Med. B Infect. Dis. Vet. Public Health, v.53, p.24-27, 2006.

VICENTE, J.; LEON, V.L.; GORTAZAR, C. et al. Antibodies to selected viral and bacterial pathogens in European wild boars from south central Spain. J. Wildl. Dis., v.38, p.649-652, 2002. 